ISSN : 2723-407X

Website: https://e-journal.iainsalatiga.ac.id/index.php/islah

\title{
Javanese Religious Humanism (Critical Study of R.M.P. Sosrokartono)
}

\author{
M. Agus Wahyudi ${ }^{1}$, Syamsul Bakri ${ }^{2}$ \\ ${ }^{1,2}$ Fakultas Ushuluddin dan Dakwah, Universitas Islam Negeri Raden Mas Said Surakarta \\ agus. wahyudiiain-surakarta.ac.id, syamsbakr99iain-surakarta.ac.id
}

\begin{abstract}
Humanism is a school in philosophy which states that humans are the center of everything, or referred to as anthropocentric. So it gives a negative impression of humanism itself. There is a discourse that God is removed or not functioned with the understanding of humanism that upholds the values of human beings. Javanese society is famous for its friendly, humanist and religious people in religion. One of the figures who came from Java was R.M.P. Sosrokartono, he has ideas and thoughts that indirectly contain humanistic values that are wrapped in the values of Javanese society. This study uses descriptive qualitative methods, the data in this study there are two forms, primary data and secondary data. The purpose of this study is to reveal the values of humanism in the thinking of R.M.P. Sosrokartono and how it is relevant to today's life. The result of this research is that there are teachings of R.M.P. Sosrokartono name is ilmu kantong bolong dan ilmu kantong kosong, in which there are humanistic values. In addition, the humanism model of R.M.P. Sosrokartono has a new variant with the humanism that developed in the West.
\end{abstract}

Keyword: Humanisme, Sosrokartono, Ilmu Kantong Bolong, Ilmu Kantong Kosong.

\begin{abstract}
Abstrak
Humanisme merupakan madzab dalam filsafat yang menyatakan bahwa manusia manusia menjadi pusat dari segalanya, atau disebut sebagai antroposentris. Sehingga memberikan kesan negatif dari humanisme itu sendiri. Terdapat wacana bahwa Tuhan disingkirkan atau tidak difungsikan dengan adanya paham humanisme yang menjunjung tinggi nilainilai yang dimiliki manusia. Masyarakat Jawa terkenal dengan orangnya yang ramah, humanis dan religius dalam beragama. Salah satu tokoh yang berasal dari Jawa adalah R.M.P. Sosrokartono, ia memiliki gagasan dan pemikiran yang secara tidak langsung di dalamnya terdapat nilai-nilai humanistik yang dibungkus dengan nilai-nilai masyarakat Jawa. Penelitian ini menggunakan metode kualitatif deskriptif, data dalam penelitian ini terdapat dua bentuk, data primer dan data sekunder. Tujuan penelitian ini untuk mengungkap nilai-nilai humanisme dalam pemikiran R.M.P. Sosrokartono dan bagaimana relevansinya dengan kehidupan sekarang. Hasil dari penelitian ini bahwa terdapat ajaran R.M.P. Sosrokartono yang bernama ilmu kantong bolong dan ilmu kantong kosong yang di dalamnya terdapat nilai-nilai humanisme. Selain itu, humanisme model R.M.P. Sosrokartono memiliki varian baru dengan humanisme yang berkembang di Barat.
\end{abstract}

Kata Kunci: Humanisme, Sosrokartono, Ilmu Kantong Bolong, Ilmu Kantong Kosong. 


\section{INTRODUCTION}

Humanism is an intellectual and literary movement that emerged in Italy in the 14th century. Humanism is also often understood as a philosophical understanding that upholds human values and dignity so that it places humans in a high position, both in theoretical reflection and in practical life. ${ }^{1}$ In Greek humanism is referred to as paideia which means education supported by humans who want to place the liberal arts as their main material or target. ${ }^{2}$ Humanism means considering the rational individual as the highest value, considering the individual as the ultimate source of value, serving the cultivation of creative development and individual moral development in a rational and meaningful manner without reference to ideas about the supernatural. ${ }^{3}$ Humanism can be interpreted as a view of life that human welfare and happiness is the main goal. ${ }^{4}$

Based on the above explanation, it can be said that humanism is a school that makes humans (individuals) the center of research and a school that wants to uphold human dignity. Based on historical records, the discourse of humanism that developed in the Western world left a negative impression, this theory ultimately favors humans and is anthropocentric (humans are the center of everything), not involving God's intervention in the process of living life. Assume God has no role in their lives. Humanism at first only wanted to free people from church dogma, then turned into an ideology and sect that wanted to get rid of God (religious rules) from human life. ${ }^{5}$ In addition to the flow of humanism, in the West there are also schools such as marxism, pragmatism, and existentialism, which is proof that the Western world has become a reference for scientific theories by scholars from around the world. ${ }^{6}$

Bunge divides humanism into two models, namely secular humanism and religious humanism. Secular humanism views humans and society on the basis of rationality, while religious humanism views humans and society based on moral values as is common in

1 Zainal Abidin, Filsafat Manusia, Memahami Manusia Melalui Filsafat, cet.I (Bandung: Rosda Karya, 2000), h. 39-41.

2 Ibid, h. 41.

${ }^{3}$ Lorens Bagus, Kamus Filsafat, cet. 2, Jilid I (Jakarta: Gramedia, 2000), h. 295.

4 Ali Mudhofir, Kamus Teori dan Aliran dalam Filsafat dan Teologi, (Yogyakarta: Gajah Mada University Press, 1996), h. 92.

${ }^{5}$ Frans Magnis-Suseno, “Agama Humanisme dan Masa Depan Tuhan” dalam Basis, NO. 05-06, Th. ke-51 (Mei-Juni 2002), h. 39.

${ }^{6}$ Zainal Abidin, Filsafat Manusia; Memahami Manusia Melalui Filsafat, h. 43. 
religion. ${ }^{7}$ Shari'ati revealed, humanism is a philosophical understanding which states that its main goal is for human salvation and perfection. ${ }^{8}$ The discourse of humanism that developed in the Western world left a negative impression, this theory in the end was very superior to humans, very anthropocentric. So it has the potential to fall into the pit of atheism, which considers God to have no role in human life.

So, from some of the definitions above, it can be concluded that religious humanism is a school that makes humans (individuals) the center who has rational values and moral values based on religious demands. Endraswara (2013) revealed that Javanese society is famous for its people who uphold human values, such as being open, easy to accept differences, wise, like to help, and very high spiritual values. Javanese society is very synonymous with mysticism, and to get the perfection of mysticism, social morality is the key. Social morality or can also be called a humanist attitude is a guideline for Javanese society and the essence of kebatinan is to build national solidarity. ${ }^{9}$

The values of humanism in Java are almost extinct, due to the erosion of modernity that has hypnotized Javanese society. Saksono and Dwiyanto argue that modernization has intensively attacked and invaded the traditional culture of the Javanese people, gradually eliminating the teachings and values of the Javanese people, including the values of Javanese humanity. At first glance they have indeed offered convenience and enjoyment, but it is only temporary, in the long run and the evidence has shown that modernity will destroy natural civilization and eventually destroy human civilization entirely. $^{10}$

One of the figures from Java who explicitly taught about human values (humanistic) was R.M.P. Sosrokartono (1877-1952) was the son of the Regent of Jepara, Raden Mas Adipati Ario Samingoen Sosroningrat and the older brother of R.A. Kartini. His great thinking was about humanism. Sosrokartono taught the Javanese people with a humanistic attitude through the ilmu kantong bolong dan ilmu kantong kosong.

\footnotetext{
${ }^{7}$ Mario Bunge, Philoshophy and Crisis: The Need for Reconstruction (New York: Prometheus Books, 200), h. 96.

8 Ali Syari'ati, Humanisme Antara Islam dan Mazhab Barat, terj. Afif Muhammad, cet. 2 (Bandung: Pustaka Hidayah, 1996), h. 39.

${ }^{9}$ Suwardi Endraswara, Kebatinan Jawa ( Yogyakarta: Lembu Jawa, 2011), h. 71-75.

10 Ignas G. Saksono dan Djoko Dwiyanto, Terbelahnya Kepribadian Orang Jawa (Yogyakarta: Keluarga Besar Marhaenis DIY, 2011), h. 219.
} 
Sosrokartono did not explicitly say that his thoughts were humanist, but implicitly when observed in his teachings and thoughts there were humanistic values.

Wahyudi had previously conducted research on Sosrokartono thoughts in 2016, his research focused on the dimensions of Sufism values contained in Sosrokartono teachings and thoughts. The results of his research revealed that in Sosrokartono teachings, such as ilmu kantong bolong dan ilmu kantong kosong, there are implied messages that teach the concepts of zuhud, patience and trust. In Sufism the concepts of zuhud, sabar and tawakal occupy as maqam or spiritual levels that must be passed by the perpetrators of Sufism. ${ }^{11}$

Based on the explanation above, the research will describe Sosrokartono's religious humanistic thought in depth, as well as analyze the relationship of Sosrokartono's humanistic thought to the nature of human life in the world and the relevance of Sosrokartono humanistic thought to life today.

\section{METHODS}

This research is a type of qualitative research with a library approach (Library Research). This study follows the way and direction of the thoughts of a philosopher in his work and those who discuss his thoughts. ${ }^{12}$ The data source used is primary data in the form of the works of R.M.P. Sosrokarto and secondary data such as journals, books, fibers related to the research theme. Data analysis in this study was carried out thematically which emphasized the qualitative content approach. ${ }^{13}$ The research is expected to be able to provide scientific contributions in the academic world about the humanistic thinking of one of the prominent Javanese figures named Sosrokartono and also as input and information to enrich the repertoire of knowledge for scholars. Practically, this research can provide an understanding to the wider community that the Javanese people highly uphold humanism based on religiosity.

\section{DISCUSSION}

\section{R.M.P. Biography Sosrokartono}

Raden Mas Pandji Sosrokartono is the son of the Regent of Jepara, Raden Mas Adipati Ario Samingoen Sosroningrat. Born in Mayong Jepara on Wednesday Pahing,

${ }^{11}$ M. Agus Wahyudi, "Psikologi Sufi: Tasawuf Sebagai Terapi," Esoterik: Ahlak dan Tasawuf 04, no. 02 (2018): 192-202.

${ }_{12}^{12}$ M. Nazir, Metode Penelitian (Jakarta: Ghalia Indonesia, 1998), h. 111.

${ }^{13}$ Syamsul Bakri, "Teaching Values of Islamic Communism in Surakarta: Issues in the First Quarter of the 20," Journal of Social Studies Education Research 11, no. 1 (2020): 192-212. 
April 10, 1877 M. Sosrokartono, the third son of Raden Mas Adipati Ario Samingoen Sosroningrat with his wife Ngasirah, daughter of cleric Mudirono from Teluk Awur. Sosrokartono lived in the Dutch and Japanese colonial times, one of the freedom fighters whose name was lost to the times. In addition, he is the older brother of R.A. Kartini, known as the Mother of Indonesian Women's Emancipation. ${ }^{14}$

In 1897 Sosrokartono completed his studies from H.B.S. (Hogere Burger School). ${ }^{15}$ Then he entered the University of Tecnische Hoges School (Technical College) in the city of Delf, Department of Engineering (1897-1925). In 1899 Sosrokartono was appointed as a member of the "Instituut Voor Land en Volkenkunde", an institution that studies and researches the culture of the ethnic groups of the archipelago. Then Sosrokartono moved to Leiden University, the Netherlands, majoring in Eastern languages and literature, and received a Doctorandus in de Oosterche Talen (Doctorate in Languages) degree. ${ }^{16}$ Sosrokartono returned to Indonesia in 1925 , his odyssey which lasted for 28 years did not make Kartono change his nationality to become a Western nation, this can be seen also from his way of life, namely Jawi bares, Jawi deles, and true Jawi (honest Javanese, original Javanese, and true Java). ${ }^{17}$

Sosrokartono is known by the public as a religious, nationalist and humanist figure. His religious attitude can be seen in his behavior and thoughts. The core of his thinking aims to find kasunyatan, but he does emphasize helping fellow humans as an intermediary to get kasunyatan or what we usually know, namely manunggaling kawulo gusti. ${ }^{18}$ Sosrokartono nationalist attitude can be seen from how he refused to accept job offers from the Dutch, and chose to pioneer education in Indonesia with his friends, such as R.M. Soerdjodipoetro (Ki Hajar Dewantoro younger brother). In addition, in his speech entitled Het Nederlandsch (Dutch in Indonesia) Sosrokartono said:

\footnotetext{
${ }^{14}$ M. Agus Wahyudi, “Ajaran Zuhud Dalam Pemikiran R.M.P. Sosrokartono” (IAIN Surakarta, 2016).

${ }^{15}$ John Tondowidjojo .T, Menapak Perjalanan Hidup Sosrokartono (Surabaya: Sanggar Bina Tama, 2012), h. 3- 4.

${ }^{16}$ Aksan,"Sosrokatono, Wong Jowo", dalam Majalah Jaya Baya, (15 Sepetember 1991), h. 10.

${ }^{17}$ R.M.P. Sosrokartono, "Serat Saking Medan", Medan, 12 Mei 1931.

${ }^{18}$ Wahyudi, "Ajaran Zuhud Dalam Pemikiran R.M.P. Sosrokartono."
} 
"I firmly declare myself to be the enemy of anyone who will turn the Dutch East Indies into a European or semi-European nation and will trample on our noble and sacred traditions and customs. As long as the Sun and Moon shine they will challenge me!' ${ }^{\prime 9}$

The humanist attitude is shown through Sosrokartono's attitude which emphasizes human values such as helping each other. This is evidenced by the establishment of Pondok Darussalam in Bandung, a place of treatment for the community. ${ }^{20}$ The place of treatment was established for people who need treatment, Sosrokartono also did not ask for compensation in dealing with people who were receiving treatment. All of them were used by Sosrokartono as a medium for his devotion to God. Sosrokartono life has long been spent in the West, but his way of thinking and his lifestyle are inseparable from the values of Javanese society. So the West dubbed him as De Javanese Prins (prince of Java). ${ }^{21}$

In addition, Sosrokartono also has a unique nickname, namely Mandor Klungsu and Djoko Pring. Foreman Klungsu means, Klungsu means tamarind seed, it is small but strong which when planted and cared for will turn into a big and sturdy tree. Tamarind trees, from trees to seeds can all be used. In addition, it has a strong and sturdy nature. Klungsu and tamarind trees are like humans and God. Djoko Pring means, Djoko is an unmarried man and Pring is bamboo. Bamboo always grows and reproduces itself, bamboo trees from leaves to roots can be useful for humans. ${ }^{22}$ The nickname reflects that Sosrokartono during his life devoted himself to God by spreading the benefits of kindness to fellow human beings.

Sosrokartono during his life did not have a wife and children. In 1942 Sosrokartono fell ill, and on Friday 8 February 1952, he died. He was buried in Sedo Mukti, Kaliputu Village, Kudus, Central Java. ${ }^{23}$ When Sosrokartono died, Bung Karno ${ }^{24}$ acknowledged that Sosrokartono was his friend and a great Indonesian son, who

${ }^{19}$ Hasna Masita, “Humanisme Dalam Pemikiran Sosrokartono” (IAIN Surakarta, 2014).

${ }^{20}$ Aksan, "Sosrokartono, Priyayi Kendel”, dalam Majalah Jaya Baya(29 September 1991), h. 22.

${ }^{21}$ Hadiwijaya, Tokoh-tokoh Kejawen Ajaran (Yogyakarta: Eule Books, 2010), h. 184-186.

${ }^{22}$ Aksan, "Sosrokartono, Priyayi Kendel", h. 22.

${ }^{23}$ Aksan, “ DRS. R.M.P. Sosrokartono Kondur Menyang Tanah Air” dalam Majalah Jaya Baya (13 Oktober 1991), h. 46.

${ }^{24}$ Bung Karno merupakan panggilan akrab Soekarno, ia lahir pada tanggal 6 Juni 1901 di Surabaya, dan merupakan Presiden Pertama Negara Republik Indonesia. Soekarno, Bung Karno Penyambung Lidah Rakyat (Jakarta: Gunung agung, 1966), h. 23. 
contributed a lot to the Indonesian nation during the colonial period, who gave many examples of humanist life. ${ }^{25}$

\section{Humanisme Religius}

Religious humanism is an understanding that has a theocentric style (God is the center). In this paper, the religious humanism that will be discussed is in the context of Islam. Although, religious humanism can be from the side of religions that believe in the existence of God, for example Islam. This type of humanism developed as an effort to compensate for the secular humanism that had existed and developed before. Because if secular humanism is not balanced with other humanism terms, such as religious humanism, then the role of religion (God) will be eliminated by humans slowly without realizing it. Marcel A Boisard argues that Islam is more than just an ideology, because Islam is a transcendental humanism created by a special society and gives birth to a moral action that is difficult to place in the framework formed by Western philosophy. Humanism does not rule out true absolute monotheism and allows for the development of virtues. $^{26}$

Humanism in the view of Islam is understood as a basic concept of humanity that does not stand in a free position, but interprets the meaning of humanizing humans by not giving up theological values. In this context, Islam views humans as representatives of Allah on earth. Humans have the capacity and knowledge to choose, and the power to choose is a gift from God. ${ }^{27}$ In the discussion of Islamic theology, this kind of understanding resembles the understanding of the Ash'ariyah in viewing human actions. ${ }^{28}$ As said by Syamsul Bakri, that the Asy'ariyah understanding is mostly followed by people who are in Malay lands, including Indonesia. ${ }^{29}$

Nurcholis Madjid said that the Abrahamic religion has a human insight based on the basic concept that humans are born naturally (clean/holy), because by nature humans have the nature of holiness, which is then expressed in holy and kind attitudes to others. ${ }^{30}$

\footnotetext{
${ }^{25}$ Aksan, "Pribadi kang Negsemake" dalam Majalah Jaya Baya, h. 19.

${ }^{26}$ Marcel A Boisard, Humanisme Dalam Islam, terj. H. M. Rasjidi (Jakarta: Bulan Bintang, 1982), h. 151 .

27 Hassan Hanafi (dkk), Islam dan Humanisme: Aktualisasi Humanisme di Tengah Krisis Humanisme Universal (Semarang: IAIN Walinsongo, 2007), h. IX.

${ }^{28}$ Harun Nasution, Falsafat Dan Mistisisme Islam (Jakarta: Bulan Bintang, 2008).

29 Syamsul Bakri, "Dakwah Sufisme Jawa Dan Potrer Keberagaman Di Era Milenial Berbasis Kearifan Lokal," Esoterik: Ahlak dan Tasawuf 05, no. 02 (2019): 267-281.

${ }^{30}$ Nurcholish Madjid, Islam Agama Kemanusiaan (Jakarta: Paradimana, 1995), h. 51.
} 
Geffre as a Christian said, authentically humans will not feel enough just with rational rules and materialistic adequacy, but humans will look for new spaces that give them space for imagination, creativity, and symbolism for their lives. For him, humanism is not just a human science, social science, literature and philosophy. More than that, humanism teaches humans to believe in god and religion in a good and right way. ${ }^{31}$

Thus, in the understanding of religious humanism the existence of God is very dominant. They believe that God has an extraordinary concept about humans, but sometimes because humans think too deep and deep, they forget God's intervention in every process of their lives. Thus, humanism and religion cannot be separated, because religion teaches a lot about humanity, and humanism in its teachings also contains the values taught in religion.

\section{Values of Religious Humanism R.M.P. Sosrokartono}

Sosrokartono has several ideas or thoughts that are embodied in the form of literary works which indirectly contain humanism values based on religiosity, as well as being a new variant in the discourse of humanism in the academic world. His thoughts include the following:

\section{Ilmu Kantong Bolong}

The term bag perforated comes from the Javanese language which means a place with a hole. The word pocket means a place to put something, for example a pocket, wallet, savings, and time deposit. The word bolong means hole or empty. ${ }^{32}$ So, the phrase "pocket hole" can be interpreted as knowledge of a place to put something, but the place has a hole and the contents continue to flow. The definition of scientific terminology is that some knowledge is coherent, empirical, systematic, measurable, and proven. ${ }^{33}$ The term bag perforated is a form of vehicle to accommodate something, both material and non-material, but it is always empty because it has a hole.

The choice of the word "bolong" does not mean that this knowledge is not meaningless. Bolong is the pure language of the Indonesian Javanese people, and is not

\footnotetext{
31 Corliss Lamont, The Philosophy of Humanism (New York: Humanist Press, 1997), h. 7-8.

32 John Tondowidjojo, Sosrokartono dan Spiritualitas dari Abad ke Abad (Surabaya: Yayasan Bina Tama, 2012), h. 115.

${ }^{33}$ Amsal Bakhtiar, Filsafat Ilmu, cet. XI ( Jakarta: Raja Grafindo, 2012), Cet. XII, h. 13.
} 
contaminated by the Dutch language, because Sosrokartono lived during the Dutch colonial period. The science of bag holes is not a science created by reason, feelings, and the exploitation of the human brain, this science is different from natural science, different in nature and nature. This knowledge is also not a philosophy, because philosophy is a manifestation of the human way of thinking. Humans think, rack their brains to capture and include the meaning and purpose of life in the world and whatever it faces. ${ }^{34}$ The science of bag holes is one of the sciences that emerges as a manifestation of the core of the human conscience, not from human reason and not from human will. This knowledge was born from the womb of a true human being as a manifestation of the true ideals of humanity.

Thus, the goodness that is done by humans or the so-called values of humanism that exist in humans is the nature of birth, the glory of God. So, humans should do good things to fellow human beings, because these are all characteristics of God-given humanity. So that human values and God's intervention cannot be separated. Everything comes from the core source, namely God.

\section{Ilmu Kantong Kosong}

Empty bag science is knowledge about places that are always empty, so empty is the result of doing hole bag science. A perforated bag causes an empty. Sosrokartono wanted to convey a very wise thing, when someone helps others, use the science of a hole bag, then whatever reward given by the person being helped will not stay in the bag, and even empty, this is because the bag is perforated. In other languages, it is called sepi ing pamrih, which means far from self-interested. Empty bag science can be achieved by eliminating self-interest and putting public interest first, being tolerant, open-minded. Ilmu kantong kosong can be achieved by risking the whole body and soul, prioritizing human traits so that they become haqqul yaqin, this is in line with the humanism of Frans Magnis Suseno. ${ }^{35}$

Based on the description of Sosrokartono's thoughts, it can be seen that Sosrokartono's humanism is not like Western humanism, which simply focuses everything on humans, for example during the Renaissance, humanism was expressed through

\footnotetext{
${ }^{34}$ Muhammada Ali, Ilmu Kantong Kosong, Kantong Bolong, dan Sunji R.M.P. Sosrokartono (Djakarta: Bhratara, 1966), h. 11-12.

${ }^{35}$ Muhammada Ali, Ilmu Kantong Kosong, Kantong Bolong, dan Sunji R.M.P. Sosrokartono (Djakarta: Bhratara, 1966), h. 11-12.
} 
classical Greek and Roman art. Sosrokartono's humanism is not just a humanities science or other human sciences, more than that, Kartono's humanism includes the nature of humans living in the world. Sosrokartono's humanism contains deep religious values, which can be applied in a religion, one of which is Islam. The essence of human life in the world is to return to God, so that Sosrokartono's humanism does not only uphold human values, but has a very sacred goal vertically (towards God).

Based on the explanation of Sosrokartono's humanism above, the writer can say that Sosrokartono's model of humanism is religious humanism, religious humanism that is Islamic and has Javanese nuances, or can be said to be Javanese humanism. Because, Kartono is a follower of Islam and at the same time Javanese. Sosrokartono is a devout Muslim, so that his thoughts do not shift from the teachings of Islam, because he is very aware that humans are indeed the most perfect creation of Allah, and humans are the caliphs on earth. ${ }^{36}$

Human relationship with God is a very sacred relationship, to achieve that humans must be able to balance the relationship between others and nature. According to Sosrokartono, to achieve a perfect relationship with God and a good relationship with nature, humans must emphasize relationships with fellow humans. Relationships with fellow humans are a way to get closer to God. Sosrokartono's teaching of humanism illustrates that humans as leaders have great responsibilities, every human being has an obligation to submit and obey God, but on the other hand Sosrokartono focuses his life on serving God by devoting himself to others. Having good relations with others, makes humans will also be wise towards nature, and will even become perfect humans or kamil humans. $^{37}$

\footnotetext{
${ }^{36}$ Mahmud Syaltut, al-Islam 'Aqidah wa Syari'ah (Kairo: Dar al-Syuruq, 1968), h. 7.

${ }^{37}$ Menurut Abdul Karim al-Jilli manusia yang sempurna adalah manusia yang telah berhasil merealisasikan seluruh kemungkinan yang ada, potensi Ketuhanan yang ada pada dirinya. Manusia sempurna atau insan kamil merupakan cermin Tuhan yang diciptakan atas nama-Nya sebagai refleksi gambaran nama-nama dan sifat-Nya. (Suwardi Endraswara, Kebatinan Jawa, h. 210). Murtadha Muthahari juga menefinisikan bahwasannya Insan Kamil yaitu bukanlah filsuf yang suntuk memeras akal, melupakan kata hati, bukan pula sufi yang tenggelam dalam samudra cinta, yang melupakan diri dan lingkungannya, tidak pula para penguasa yang atas nama Tuhan memupuk kekuasaan, kehormatan, dan kekayaan, bukan pula kaum humanis yang demi rasa kemanusiaannya mengabaikan tugasnya sebagai hamba Tuhan, tetapi manusia sempurna adalah manusia yang mampu memperdayakan nalar dan cinta untuk mengenal Tuhan. Murtadha Muthahari, Potret Insan Kamil; Meneropong Karakteristik Manusia Sempurna (Yogyakarta: Bina Media,2005), h. 53.
} 
According to Taufik Abdullah, the acculturation of Javanese and Islamic culture takes a dialogical form, so that it is understood that the development of Islam and Javanese culture communicates in the form of a socio-religious structure. ${ }^{38}$ It can be hypothesized that kejawen is a syncretism of Javanese culture and Islamic Sufism. As for Kejawen Islam has several principles, from these principles it will be seen, some of Sosrokartono's teachings are in accordance with these principles. Among them:

First, manembah ing gusti, manembah is the main key of worship for every belief. The essence of worship is worship. Religion recognizes worship by praying, while kebatinan tends to call it manembah. The two terms are actually similar, because they are related to the relationship between humans and God. Religion and kebatinan are not the same, both have special differences, religion puts emphasis on panembah while kebatinan emphasizes nobility and perfection of life. ${ }^{39}$

Second, sepi ing pamrih lan rame ing gawe, meaning emptying personal ambitions that can harm others and like to work or be easy-going. Selfishness hinders the achievement of the goodness of the world and the purity of life. ${ }^{40}$ Pamrih is seen in three passions, namely always wanting to be the first person, thinking that he is always right, and only paying attention to his own needs. ${ }^{41}$ The sepi ing pamrih attitude that has been described above greatly influenced Sosrokartono's humanistic thinking, this attitude gave birth to the ilmu kantong bolong dan ilmu kantong kosong. This attitude can be shown to fellow human beings as well as to God. For him, selfless people are the same as weak people. $^{42}$

Rame ing gawe has the meaning of liking to work or being easy-going. People who are busy ing gawe always use their intentions to work and never be unemployed. Countries will develop and develop with the sweat of people who like to work. Work productivity will help other people to feel the sweat seep from their work. Wherever people can give if they have. If you don't have it then what will then be given, other than

\footnotetext{
${ }^{38}$ Taufik Abdullah, "Islam dan Pembentukan Tradisi di Asia Tenggara" dalam Taufik Abdullah dan Sharon Siddique Tradisi dan Kebangkitan Islam di Asia Tenggara (Jakarta: LP3ES, 1989), h. 58.

${ }^{39}$ Suwardi Endraswara, Kebatinan Jawa dan Jagad Mistik Kejawen (Yogyakarta: Lembu Jawa, 2011), h. 70.

${ }^{40}$ Ibid. h. 130.

${ }^{41}$ Adityo Jatmiko, Tafsir Ajaran Serat Wedhatama (Yogyakarta: Pura Pustaka, 2005), h. 65.

${ }^{42}$ Aksan, Ilmu dan Laku Drs. RMP.Sosrokartono, h. 18.
} 
diligent work. Hard work is also a means to do good and be useful to society and is a very noble behavior. People will appreciate others who want to work diligently and sincerely.

Third, menang tanpa ngasorake, sugih tanpa bandha means winning without defeating, rich without wealth. Kartono never fought against the invaders by defeating and demeaning, he preferred to face each other, preferring to consult because with deliberation there will be no war, fight, violence, and death.

Sugih without bondho, at first glance, this is illogical if viewed from the point of view of economic principles and materialism. However, viewed from the perspective of idealism, it has a deeper meaning, namely inner wealth. In order not to be biased, here will be described the difference between outer and inner wealth, without needing to say which is good and which is bad. In this case, the emphasis lies on how to understand it and also depends on the needs of life according to their needs.

Fourth, digdaya tanpa aji, nglurug tanpa bala, the fourth principle is already in his teachings written on his tombstone. He teaches people who are magically mandraguna without having to have magic, amulets, or other sacred objects. Powerful because of himself, can be because of intelligence, because of piety because of excellence in human relations and so on. Thus, one can conquer one's opponent not by force but by affection.

From the four principles of Kejawen Islam that the writer describes above, it is seen that Kartono also practiced these principles during his lifetime. Kartono tried his best to implement these principles and understand them to the community at that time. So, there is no contradiction between Kejawen Islam and Kartono's teachings. This proves that Sosrokartono is a follower of kejawen Islam. Thus, the teachings of humanism that the author has expressed above are religious humanism, Islam and Javanese nuances, in short, kejawen Islamic humanism.

\section{CONCLUSION}

Sosrokartono religious humanism is an effort to find the essence of life and an effort to serve a servant to God. For him, serving fellow human beings is an obligatory worship, and an effort to be taqorrub to Allah. Sosrokartono's model of humanism is religiousIslamic and has Javanese nuances, thus forming a humanist and religious Javanese identity. Departing from the search for the essence of life in the world, Sosrokartono humanistic thoughts can be understood through of Ilmu Kantong Bolong and Ilmu Kantong Kosong. Both are sciences that teach devotion to fellow human beings and to God. The relationship between Sosrokartono's humanism and the nature of life in the world is very clear, for him it is the search for the essence of life in the world that gives 
birth to humanist thinking. Getting the essence of life in the world, then humans find a way to get closer to God. If it is related to the problems of Indonesian society today, Kartono's humanism can be used as a solution, and is still relevant to be applied. The number of crimes that harm humans is caused by the distance humans are now from God, this causes moral decline and crime is rampant. The Indonesian people who should have and uphold human values are now actually impressed by the crisis of human values. Therefore, Sosrokartono's model of thought with nuances of humanism can be used as a solution to overcome it.

\section{REFERENCES}

Abdullah, T. (1989). "Islam dan Pembentukan Tradisi di Asia Tenggara" dalam Taufik Abdullah dan Sharon Siddique Tradisi dan Kebangkitan Islam di Asia Tenggara (Jakarta: LP3ES).

Abidin, Z. (2000). Filsafat Manusia, Memahami Manusia Melalui Filsafat. (Bandung: Rosda Karya)

Aksan, "DRS. R.M.P. Sosrokartono Kondur Menyang Tanah Air” dalam Majalah Jaya Baya (13 Oktober 1991).

Ali, M. (1966). Ilmu Kantong Kosong, Kantong Bolong, dan Sunji R.M.P. Sosrokartono (Djakarta: Bhratara).

Bagus, L. (2000). Kamus Filsafat. (Jakarta: Gramedia).

Bakhtiar, A. (2012). Filsafat Ilmu. (Jakarta: Raja Grafindo).

Bakri, S. (2019). "Dakwah Sufisme Jawa Dan Potrer Keberagaman Di Era Milenial Berbasis Kearifan Lokal.” Esoterik: Ahlak dan Tasawuf 05, no. 02: 267-28.

Bakri, S. (2019). Pemikiran Filsafat Manusia Ibn Miskawaih: Telaah Kitab Tahdibz alAkhlak. Jurnal Al-A'raf. XV, 01.

Bakri, S. (2020). "Teaching Values of Islamic Communism in Surakarta: Issues in the First Quarter of the 20.” Journal of Social Studies Education Research 11, no. 1: 192-212.

Bakri, S. (2020). Akhlaq Tasawuf: Dimensi Spiritual dalam Kesejarahan Islam. Sukoharjo: EFUDEPRESS.

Bunge, M. (2000). Philoshophy and Crisis: The Need for Reconstruction. (New York: Prometheus Books).

Endraswara, S. (2011). Kebatinan Jawa dan Jagad Mistik Kejawen. (Yogyakarta: Lembu Jawa). 
Endraswara, S. (2011). Kebatinan Jawa. (Yogyakarta: Lembu Jawa).

Hadiwijaya. (2010). Tokoh-tokoh Kejawen Ajaran. (Yogyakarta: Eule Books).

Hanafi, H. (2007). Islam dan Humanisme: Aktualisasi Humanisme di Tengah Krisis Humanisme Universal. (Semarang: IAIN Walinsongo).

Jatmiko, A. (2005). Tafsir Ajaran Serat Wedhatama. (Yogyakarta: Pura Pustaka).

Lamont, C. (1997). The Philosophy of Humanism. (New York: Humanist Press).

Madjid, N. (1995). Islam Agama Kemanusiaan. (Jakarta: Paradimana).

Marcel A. B. (1982). Humanisme Dalam Islam, terj. H. M. Rasjidi. (Jakarta: Bulan Bintang).

Masita, H. "Humanisme Dalam Pemikiran Sosrokartono” (IAIN Surakarta, 2014).

Mudhofir, A. (1996). Kamus Teori dan Aliran dalam Filsafat dan Teologi. (Yogyakarta: Gajah Mada University Press).

Muthahari, M. (2005). Potret Insan Kamil; Meneropong Karakteristik Manusia Sempurna, (Yogyakarta: Bina Media).

Nasution, H. (2008). Falsafat Dan Mistisisme Islam. (Jakarta: Bulan Bintang)

Nazir, M. (1998). Metode Penelitian. (Jakarta: Ghalia Indonesia).

Saksono, I. G. \& Djoko Dwiyanto. (2011). Terbelahnya Kepribadian Orang Jawa. (Yogyakarta: Keluarga Besar Marhaenis DIY).

Soekarno. (1966). Bung Karno Penyambung Lidah Rakyat. (Jakarta: Gunung agung).

Suseno, F. M. (2002). “Agama Humanisme dan Masa Depan Tuhan” dalam Basis, NO. 05-06, Th. ke-51 (Mei-Juni).

Syaltut, M. (1968). al-Islam 'Aqidah wa Syari'ah. (Kairo: Dar al-Syuruq).

Syari'ati, A. (1996). Humanisme Antara Islam dan Mazhab Barat, terj. Afif Muhammad. (Bandung: Pustaka Hidayah).

Tondowidjojo, J. (2012). Sosrokartono dan Spiritualitas dari Abad ke Abad. (Surabaya: Yayasan Bina Tama).

Wahyudi, M. A. (2016). “Ajaran Zuhud Dalam Pemikiran R.M.P. Sosrokartono.” IAIN Surakarta.

Wahyudi, M. A. (2018). "Psikologi Sufi: Tasawuf Sebagai Terapi." Esoterik: Ahlak dan Tasawuf 04, no. 02: 192-202.

Wahyudi, M. A. (2020). Psychological Well-Being Sufism Practitioners as A Sufistic Conceling. Jurnal Konseling Religi, 11, 01. 145-157. 